\title{
Gambaran Dukungan Sosial dan Penyesuaian Diri pada Perempuan Pegawai Negeri Sipil Pra Pensiun di Provinsi Bali
}

\author{
Dewa Ayu Dyah Puteri Pratiwi dan Made Diah Lestari \\ Program Studi Sarjana Psikologi, Fakultas Kedokteran, Universitas Udayana \\ mdlestari@gmail.com
}

\begin{abstract}
Abstrak
Masa pra pensiun merupakan masa-masa yang mencemaskan bagi individu yang belum siap untuk memasuki masa pensiun. Penyesuaian diri menjadi pilihan individu untuk mengatasi kecemasan yang dialami. Karakteristik perempuan menjelang masa pensiun cenderung untuk mengomunikasikan permasalahan yang dihadapi sehingga perempuan membutuhkan dukungan sosial dari lingkungan sekitar. Dukungan sosial berperan penting dalam kesiapan individu untuk menghadapi masa pensiun. Lingkungan yang mendukung akan mempermudah proses penyesuaian diri individu terhadap kondisi kecemasan yang dihadapi. Tujuan dari penelitian ini adalah untuk mengetahui gambaran dukungan sosial dan penyesuaian diri pada perempuan pra pensiun Pegawai Negeri Sipil di Provinsi Bali. Metode penelitian yang digunakan peneliti adalah penelitian kualitatif dengan pendekatan fenomenologi. Pengumpulan data dilakukan melalui in depth interview dan observasi pada tiga responden penelitian. Hasil penelitian menunjukkan bahwa gambaran masa pra pensiun yang dialami oleh responden terbagi menjadi aspek fisik, emosional dan perilaku. Tindakan yang dilakukan responden untuk mencapai kesiapan masa pensiun terdiri dari tindakan yang berorientasi terhadap diri sendiri serta tindakan yang berorientasi terhadap orang lain. Faktor yang memengaruhi tindakan untuk mencapai kesiapan terdiri dari faktor pendukung serta faktor penghambat. Adanya persepsi positif, menerima informasi positif mengenai masa pensiun dari lingkungan kerja serta tersedianya dukungan dari keluarga merupakan faktor pendukung responden untuk mencapai kesiapan. Penelitian ini juga menemukan bahwa bentuk dukungan keluarga pada perempuan pra pensiun terdiri dari place to share and discuss, energizer, be reminder, financial source, fasilitator, serta taking over the job.
\end{abstract}

Kata kunci: Dukungan sosial, Penyesuaian diri, Perempuan, Pra Pensiun.

\begin{abstract}
Pre-retirement is a perturbing period for individuals who are not ready to retire. Adjustment becomes an individual choice to overcome the anxiety experienced. Since the female characteristic of retirement tends to communicate the problems faced, so women need social support from the surrounding environment. Social support plays an important role in the individual's readiness to face retirement. A supportive environment will facilitate the process of individual adjustment to the anxiety conditions faced. The purpose of this study was to investigate the description of social support and adjustment in pre-retirement women of Civil Servants in Bali Province. Research method used by researcher was a qualitative research with phenomenology approach. The data were collected through in depth interview and observation on three respondents. The results showed that the pre-retirement picture experienced by respondents is divided into physical, emotional and behavioural aspects. Actions taken by respondents to achieve retirement preparedness consist of self-oriented actions and actions oriented towards others. Factors that influence the action to achieve readiness consist of supporting factors and inhibiting factors. Positive perceptions, receiving positive information about retirement from the work environment and the availability of family support is a factor supporting respondents to achieve readiness. The study also found that the form of family support for pre-retirement women consists of place to share and discuss, energizer, reminder, financial source, facilitator, and taking over the job.
\end{abstract}

Key words: Social support, Adjustment, Women, Pre-retirement. 


\section{LATAR BELAKANG}

Masa pensiun merupakan masa-masa yang mencemaskan bagi para pensiunan, terutama yang belum siap secara psikologis dan finansial untuk menghadapi masa pensiun. Sebagian orang yang memiliki persiapan yang baik dalam menghadapi masa pensiun akan merasakan ketenangan dan kebahagiaan pada masa pensiun sedangkan pada yang tidak mempersiapkan masa pensiun dengan baik rentan terhadap depresi karena menganggap berbagai perubahan yang dialami adalah stressor yang mengganggu kehidupan sehari- hari (Hermaningtyas, 2015). Persiapan menghadapi masa pensiun dilakukan sebelum individu memasuki masa pensiun atau disebut sebagai masa pra pensiun.

Kenyataannya pada masa pra pensiun timbul kekhawatiran terhadap masa pensiun yang akan dijalani sehingga individu tidak dapat fokus dengan persiapan yang akan dilakukan. Hal ini dapat disebabkan karena beban mental yang ada dalam dirinya seperti, perasaan akan berkurangnya penghormatan orang lain terhadap dirinya, ketakutan akan kegiatan yang belum jelas untuk dijalani ketika pensiun nanti, atau faktor lainnya seperti berkurangnya pendapatan, serta fasilitas yang diterima (Fardilla, Rahmi \& Putra, 2014). Berdasarkan fenomena tersebut, apabila seseorang tidak mempersiapkan diri dalam menghadapi masa pensiun maka peristiwa pensiun akan menjadi stressor bagi kehidupan mereka.

Menurut Greenberg (2004) stressor adalah sesuatu yang berpotensi menimbulkan stres. Berdasarkan penelitian yang dilakukan oleh Holmes dan Rahe (1967), pensiun menduduki urutan ke-10 dari 25 jenis stressful event yang ditemukan. Kondisi stres muncul ketika individu tidak mampu menerima kondisi pensiun dengan baik, sehingga munculah gangguan psikologis dan ketidaksehatan mental seperti cemas, stres, dan depresi. Perubahan kondisi psikologis seperti cemas, stres, dan depresi yang diakibatkan oleh masa pensiun dapat teratasi dengan penyesuaian diri (Parkinson, dalam Biya dan Suarya 2016). Penyesuaian diri yang baik membutuhkan kematangan dalam setiap bagian tingkah laku individu, termasuk bidang sosial, emosi, moral dan agama.

Penyesuaian diri didefinisikan sebagai interaksi yang kontinu dengan diri sendiri, yaitu apa yang telah ada pada diri sendiri, tubuh, perilaku, pemikiran serta perasaan, dengan orang lain dan dengan lingkungan (Calhoun dalam Kumalasari, 2012). Menurut Hurlock (1980) dukungan dari lingkungan sekitar memiliki peranan bagi seseorang yang mengalami masa transisi penting dalam kehidupannya seperti memasuki masa pensiun. Menurut Cohen dan Hoberman (dalam Isnawati, 2013) dukungan dari lingkungan sekitar yang disebut pula sebagai dukungan sosial mengacu pada berbagai sumber daya yang disediakan oleh hubungan antarpribadi seseorang. Dukungan sosial sebagai model dukungan yang dihasilkan dari interaksi antar pribadi yang melibatkan aspek emosi, penilaian, informasi dan instrumen sehingga dapat mengurangi beban yang diterima individu.

Kumalasari (2012) menemukan bahwa individu yang memiliki persepsi positif terhadap dukungan sosial, menunjukkan bahwa individu tersebut menyadari akan keadaan di sekitarnya dan juga menyadari diri individu itu sendiri, sehingga dapat menerima dan merasakan manfaat dukungan sosial. Dukungan sosial juga menjadi bagian dari individu yang memutuskan untuk berkarier serta menjalankan peran lain selain sebagai seorang pekerja. Sesuai dengan yang dialami pekerja perempuan, menurut kodratnya sebagai seorang perempuan yang bertindak sebagai ibu dan istri, hal ini tentu akan menimbulkan konflik tersendiri bagi pekerja perempuan. Adanya konflik antar peran tidak menurunkan keinginan seorang perempuan untuk tetap bekerja (Rachmaputri \& Haryanti, 2015).

Berdasarkan data Badan Pusat Statistik (BPS) Provinsi Bali bahwa, pada tahun 2016 terdapat 1.106 .749 penduduk perempuan Provinsi Bali yang berstatus sebagai pekerja. Pekerjaan yang dilakukan bervariasi terdiri dari sektor formal maupun informal. Perempuan Bali yang bekerja di sektor formal dihadapkan pada sejumlah tantangan untuk menyelesaikan pekerjaannya di tempat kerja dengan baik tanpa mengabaikan pemenuhan peran kehidupan mereka sebagai Perempuan Bali yang secara kultural cukup kompleks (Adityawira \& Supriyadi, 2017). Sektor formal digunakan dalam pengertian pekerja bergaji atau harian dalam pekerjaan yang permanen (Breman dalam Nilakusumawati \& Susilawati, 2012).

Berbagai jenis pekerjaan disediakan oleh pihak pemerintah maupun pihak swasta. Masyarakat memiliki pandangan bahwa pekerjaan yang disediakan oleh pemerintah seperti Pegawai Negeri Sipil (PNS) adalah profesi yang sangat menjanjikan. Setiap tahun pemerintah membuka penerimaan pegawai negeri sipil dan setiap tahunnya pendaftar CPNS semakin bertambah. Data Badan Pusat Statistik (BPS) tahun 2016, tercatat sebanyak 40.712 orang pekerja perempuan di Provinsi Bali yang bekerja sebagai Pegawai Negeri Sipil. Pegawai Negeri Sipil merupakan salah satu pekerjaan yang paling diminati oleh masyarakat di Provinsi Bali selain jenis pekerjaan di bidang pertanian dan pariwisata. Alasan pemilihan pekerjaan sebagai Pegawai Negeri Sipil terkait jam kerja yang teratur, ketika pensiun Pegawai Negeri Sipil (PNS) memperoleh tunjangan pensiun oleh pemerintah.

Penelitian yang dilakukan oleh Dinsi (2006) di Indonesia, pihak yang paling takut menghadapi masa pensiun adalah Pegawai Negeri Sipil (PNS). Hal ini terjadi karena pegawai negeri sipil mempunyai aktifitas rutin yang dilakukannya selama bertahun-tahun serta tunjangan yang diperoleh selama bekerja menyebabkan perubahan yang signifikan terhadap gaya hidup yang akan dihadapi setelah pensiun. Budaya kerja yang dimiliki Pegawai Negeri Sipil semakin memicu timbulnya kecemasan menghadapi masa pensiun. Fenomena kecemasan terjadi pada Pegawai Negeri Sipil karena pekerjaan sebagai Pegawai Negeri Sipil memiliki karakteristik kerja seperti bekerja sesuai dengan apa yang telah ditetapkan oleh aturan, kerja rutin, cenderung menunggu perintah dari atasan, kehidupan yang terjamin hingga hari tua karena memiliki tunjangan pensiun, status sosial yang tinggi di masyarakat, serta resiko untuk di PHK cenderung kecil.

Walaupun telah memiliki tunjangan masa pensiun tetapi tunjangan yang diberikan tidak sebesar gaji yang mereka dapatkan sewaktu masih aktif bekerja. Individu yang dulunya aktif bekerja memiliki jabatan dan status, saat pensiun akan 
kehilangan pekerjaannya (Herani \& Indriana, 2015). Para Pegawai Negeri Sipil yang telah habis masa purna tugasnya atau pensiun, mengalami mental shock (guncangan kejiwaan) akibat perubahan yang terjadi pada kehidupannya setelah pensiun. Ketika menjelang akhir masa kerjanya, mereka tampak kurang beraktivitas dan sering sakit-sakitan. Mental shock ini terjadi, karena adanya ketakutan tentang apa yang harus dihadapi kelak, ketika masa pensiun tiba. Terasa ada sesuatu yang hilang dari dirinya, karena pekerjaan dan jabatan yang selama ini dipegang, harus ditinggalkan.

Masa pensiun dapat dialami oleh Pegawai Negeri Sipil perempuan ataupun laki-laki. Penelitian menyatakan bahwa perempuan lebih banyak mendapatkan permasalahan dalam menghadapi masa pensiun daripada laki-laki, perempuan mungkin membutuhkan lebih banyak waktu untuk beradaptasi dengan masa pensiun (Kim \&Moen; Price \& Joo dalam Matlin, 2008). Hal tersebut dikarenakan sifat feminitas pada perempuan yang berkorelasi kuat dengan neurotisme, kurangnya ketegasan serta kurangnya harga diri menjadikan seorang perempuan lebih panik dan lebih cemas dalam menghadapi pensiun, otomatis orang tersebut kurang mempersiapkan pensiunnya dengan baik, bahkan bisa saja memiliki ketergantungan yang tinggi terhadap orang lain akan masa depannya setelah pensiun kelak (Safitri, 2013). Permasalahan lain yang dihadapi perempuan menjelang masa pensiun salah satunya adalah menopause.

Dalam menanggapi permasalahan yang dialami laki-laki dan perempuan juga memiliki perbedaan yaitu, ketika mendapatkan masalah maka perempuan tersebut ingin mengkomunikasikanya dengan orang lain dan memerlukan dukungan atau bantuan orang lain, sedangkan pada laki-laki cenderung memikirkan masalahnya sendiri dan mencari jalan keluarnya (Pease dalam Basuki, 2015). Hal ini diperkuat oleh hasil studi pendahuluan peneliti terhadap perempuan yang bekerja sebagai Pegawai Negeri Sipil di Provinsi Bali responden berinisial AG dan DS yang menyatakan, dukungan keluarga menjadi salah satu faktor penting dalam kesiapan menghadapi masa pensiun. Sumber dukungan yang diharapkan menjelang masa pensiun adalah dukungan dari keluarga.

Dukungan dari keluarga diharapkan mampu menciptakan rasa nyaman pada masa pensiun. Diketahui pula bahwa selain dukungan dari keluarga, dalam menghadapi masa pensiun rekan-rekan kerja yang memiliki informasi ataupun telah memiliki pengalaman pensiun kerap membagikan informasi mengenai masa pensiun sehingga dapat memberikan gambaran kepada pegawai yang akan menghadapi masa pensiun (Pratiwi, 2017). Berdasarkan pemaparan di atas, maka peneliti tertarik untuk mengangkat fenomena tersebut menjadi sebuah permasalahan dalam penelitian ini. Penelitian ini hendak melihat bentuk penyesuaian diri dan faktor-faktor yang mendukung bentuk penyesuaian diri pada perempuan pra pensiun Pegawai Negeri Sipil (PNS) di Provinsi Bali.

\section{METODE PENELITIAN}

Metode penelitian yang digunakan dalam penelitian ini adalah metode penelitian kualitatif. Pemilihan metode kualitatif bertujuan untuk memahami pengalaman individu dalam memperoleh dukungan sosial serta pengalaman dalam menyesuaikan diri ketika menghadapi masa pensiun. Melalui metode kualitatif, diharapkan informasi yang diperoleh lebih mendalam terkait dengan isu tersebut. Penelitian kualitatif yang digunakan untuk memahami isu-isu sensitif dinilai sesuai dengan penelitian ini, karena masa pra pensiun merupakan salah satu isu sensitif akibat banyak perubahan yang terjadi pada diri individu.

Pendekatan yang digunakan dalam penelitian ini adalah pendekatan fenomenologi. Fenomenologi diartikan sebagai pengalaman subjektif atau pengalaman fenomenologikal dan suatu studi tentang kesadaran dari perspektif pokok seseorang (Husserl dalam Moleong, 2015). Menurut Creswell (2015) fenomena merupakan hal yang ditekankan pada studi fenomenologi. Fenomena adalah suatu konsep yang sedang dialami oleh subjek dalam studi, yang dapat mencakup konsep psikologis. Berdasarkan pemaparan diatas, pendekatan fenomenologi yang fokus pada pengalaman subjektif individu sesuai dengan

tujuan penelitian yaitu bagaimana pengalaman subjektif perempuan pegawai negeri sipil terkait dengan dukungan sosial dan penyesuaian diri ketika berada pada masa pra pensiun. Pendekatan ini juga dapat digunakan untuk memahami arti dari sebuah peristiwa seperti masa pensiun serta bagaimana kaitan dari orang-orang yang berada pada peristiwa tersebut.

\section{Responden Penelitian}

Teknik pemilihan responden yang digunakan adalah teknik purposive sampling. Kriteria responden yang digunakan dapat dijelaskan sebagai berikut: (1) Berjenis kelamin perempuan, (2) rentang usia 55-57 tahun, (3) berstatus Pegawai Negeri Sipil (PNS), berdomisili di Provinsi Bali

\section{Teknik Penggalian Data}

Dalam penelitian ini, teknik pengumpulan data yang digunakan adalah wawancara dan observasi yang dijelaskan sebagai berikut:

\section{Wawancara}

Wawancara adalah percakapan dengan maksud tertentu. Percakapan itu dilakukan oleh dua pihak, yaitu pewawancara (interviewer) yang mengajukan pertanyaan dan terwawancara (interviewee) yang memberikan jawaban atas pertanyaan (Moleong, 2015). Lincoln dan Guba (dalam Moleong, 2015) menyatakan tujuan dalam pelaksanaan wawancara antara lain mengkonstruksikan mengenai orang, kejadian, organisasi, perasaan, motivasi, tuntutan, kepedulian dan lain-lain, memverifikasi, mengubah, dan memperluas informasi yang diperoleh dari orang lain, baik manusia maupun bukan manusia (triangulasi) serta memverifikasi, mengubah dan memperluas konstruksi yang dikembangkan oleh peneliti sebagai pengecekan anggota. 


\section{Observasi}

Morris (dalam Hasanah, 2016) mendefinisikan observasi sebagai aktivitas mencatat suatu gejala dengan bantuan instrumen-instrumen dan merekamnya dengan tujuan ilmiah atau tujuan lain. Pada penelitian ini, observasi yang digunakan adalah observasi non-partisipan. Peran peneliti dalam observasi non-partisipan adalah sebagai pengamat independen. Proses observasi dalam penelitian ini dilakukan bersamaan dengan proses wawancara, hal-hal yang akan diamati oleh peneliti dalam proses observasi adalah kondisi lingkungan kerja responden, hubungan responden dengan rekan kerja dan keluarga, interaksi dalam lingkungan sosial, serta interaksi responden dengan peneliti selama wawancara berlangsung.

\section{Catatan Lapangan}

Menurut Bogdan dan Biklen (dalam Moleong, 2015) catatan lapangan adalah catatan tertulis tentang apa yang didengar, dilihat, dialami, dan dipikirkan dalam rangka pengumpulan data dan refleksi terhadap data dalam penelitian kualitatif. Catatan lapangan menjadi pilihan utama, karena memungkinkan peneliti memahami makna yang terkandung di lapangan yang diamati kemudian mencatatnya. Catatan lapangan terdiri dari catatan deskriptif yang berisi gambaran tempat, orang dan kegiatannya (termasuk pembicaraan dan ekspresinya).

\section{Teknik Analisis Data}

Analisis data dalam penelitian kualitatif, dilakukan pada saat pengumpulan data berlangsung, dan setelah selesai pengumpulan data dalam periode tertentu. Menurut Strauss dan Corbin (1990) mengungkapkan teknik analisis data yang dilakukan dalam penelitian ini adalah theoretical coding. Theoretical coding terdiri dari tiga tipe proses yaitu open coding, axial coding, dan selective coding.

Open coding

Open coding merupakan proses meneliti data dan memampatkannya menjadi kategori analisis awal atau dengan istilah lain disebut kode-kode. Pada tahap ini peneliti memfokuskan pada data aktual dan menerapkan kode untuk tema-tema tertentu, peneliti membentuk kategori awal dari informasi mengenai fenomena yang dipelajari kemudian membaginya dalam kategori-kategori (Creswell, 2015)

\section{Axial coding}

Axial coding adalah prosedur penempatan data kembali dengan cara-cara baru kemudian membuat kaitan antar kategori. Pada axial coding, peneliti memulai dengan himpunan kode-kode awal atau konsep-konsep awal yang terorganisasi (Strauss \& Corbin, 1990). Pengkodean pada tahap ini diawali dengan menentukan jenis kategori kemudian dilanjutkan dengan menemukan hubungan antar kategori atau antar sub-katergori.

Selective coding

Selective coding merupakan tahap terakhir dalam pengkodean. Pada tahap ini akan dilakukan identifikasi suatu alur cerita dan menuliskan cerita yang mengintegrasikan kategori-kategori pada model axial coding (Creswell, 2015).

\section{HASIL PENELITIAN}

Berdasarkan penelitian yang dilakukan, diperoleh hasil mengenai tindakan penyesuaian diri dan faktor-faktor yang memengaruhi penyesuaian diri, yang dapat dijelaskan dalam Bagan 1. Gambaran penyesuaian diri pada perempuan pra pension (terlampir).

\section{Tindakan untuk mencapai kesiapan menghadapi masa pensiun}

Dalam menghadapi berbagai perubahan menjelang masa pensiun diperlukan berbagai tindakan yang dilakukan responden untuk mencapai kesiapan diri menjelang masa pensiun, tindakan tersebut antara lain:

$\underline{\text { Self }}$

Pertama, sebelum akhirnya responden menjalani masa pensiun, responden melakukan beberapa persiapan yang bertujuan untuk mengisi waktu luang. Rencana kegiatan yang dipersiapkan responden telah disusun sedemikian rupa agar responden memiliki gambaran kegiatan untuk mengisi waktu luang. Planning yang dilakukan oleh responden antara lain membuka usaha agar menghasilkan uang, melakukan hobi untuk mengisi waktu luang, mengikuti kegiatan organisasi, berpartisipasi dalam kegiatan keagamaan

Kedua, menerapkan pola hidup sederhana menjelang masa pensiun merupakan cara responden untuk mencapai kesiapan, mengurangi perilaku konsumtif dengan belajar untuk hidup sederhana sebagai bentuk mengurangi pengeluaran responden menjelang masa pensiun.

Ketiga, upaya mencapai kesiapan dalam menghadapi masa pensiun dilakukan responden dengan cara menciptakan perasaan nyaman. Merubah situasi yang kurang menyenangkan menjadi situasi yang menyenangkan serta tidak memfokuskan diri pada hal-hal yang dapat merugikan responden menjadikan perasaan nyaman muncul dengan sendirinya.

Keempat, Responden pada penelitian ini menyebutkan bahwa bersyukur membuat responden menerima kondisi yang dijalani serta menimbulkan perasaan tenang dalam menghadapi berbagai perubahan yang terjadi menjelang masa pensiun.

Others

Pertama, melakukan partisipasi dalam berbagai kegiatan di masyarakat menjadi pilihan responden untuk mencapai kesiapan menghadapi masa pensiun. Responden merasa ketika aktif bekerja, kesempatan untuk terjun ke masyarakat menjadi berkurang. Memasuki masa pensiun, responden menginginkan untuk aktif bersosialisasi dengan masyarakat.

Kedua, responden pada penelitian ini menyatakan bahwa dengan cara tidak menyinggung perasaan orang lain adalah upaya untuk melakukan perbuatan baik yang bertujuan menciptakan masa pensiun sesuai yang diharapkan oleh responden. 
Faktor-faktor yang memengaruhi tindakan kesiapan menghadapi masa pensiun

Keberhasilan perempuan pada masa pra pensiun untuk mencapai kesiapan dipengaruhi oleh beberapa hal, salah satunya adalah faktor-faktor yang mendukung responden dalam menghadapi masa pra pensiun.

Faktor pendukung

Pertama, adanya persepsi positif pensiun memberikan penambahan waktu luang Persepsi positif mengenai waktu luang merupakan salah satu hal yang memengaruhi tindakan responden. Pandangan positif terhadap banyaknya waktu luang yang dimiliki ketika pensiun menimbulkan gambaran mengenai keadaan pensiun yang sebenarnya. Persepsi positif mengenai pentingnya dukungan keluarga karena pada masa pensiun interviewee lebih banyak menghabiskan waktu dengan keluarga.

Kedua, mencari dan memperoleh informasi positif tentang masa pensiun di lingkungan kerja Informasi yang diperoleh responden dari teman responden yang masih aktif bekerja maupun yang sudah pensiun menyebabkan responden memiliki gambaran mengenai masa pensiun. Ketiga responden menyatakan bahwa informasi yang diperoleh umumnya informasi yang bersifat positif antara lain informasi terkait kegiatan, fisik yang semakin baik setelah pensiun serta kehidupan sosial setelah pensiun.

Ketiga, adanya dukungan dari keluarga merupakan salah satu faktor pendukung untuk mencapai kesiapan dalam menghadapi masa pensiun. Dukungan keluarga terdiri dari berbagai bentuk sesuai dengan kondisi yang dihadapi oleh individu. Penjelasan mengenai dukungan keluarga menjelang masa pensiun lebih lanjut akan dipaparkan pada tabel 6 . Bentuk dukungan keluarga.

Faktor Penghambat

Berbeda dengan faktor yang mendukung responden untuk mencapai kesiapan, berikut adalah faktor penghambat responden dalam mencapai penyesuaian yaitu adanya konflik dengan anggota keluarga menurut responden merupakan faktor yang menjadi hambatan untuk responden dalam mencapai penyesuaian. keluarga yang diidentikkan sebagai kelompok sosial yang pada masa pensiun akan lebih banyak menghabiskan waktu dengan responden menjadi sumber konflik bagi responden. Konflik yang dirasakan responden antara lain dengan menantu serta suami secara tidak langsung menjadi kendala untuk responden dalam mencapai penyesuaian.

\section{Bentuk dukungan keluarga pada perempuan pra pensiun}

Dalam menghadapi masa pra pensiun, terdapat berbagai perubahan yang dirasakan oleh tiap individu. Perubahan yang terjadi dapat disadari maupun tidak disadari secara langsung oleh individu, adanya perubahan mungkin saja berdampak kepada kehidupan sosial individu dengan lingkungan sekitarnya. Dalam menghadapi perubahan yang dirasakan oleh individu menjelang pensiun, terdapat beberapa bentuk dukungan keluarga yang bertujuan untuk meringankan beban individu dalam menghadapi masa pensiun, yang dapat dilihat pada Bagan 2. Dukungan keluarga (terlampir).

\section{PEMBAHASAN DAN KESIMPULAN}

\section{Tindakan untuk mencapai kesiapan menghadapi masa pensiun}

Kondisi yang dialami menjelang masa pensiun merupakan suatu bentuk kecemasan yang dirasakan oleh individu. Perubahan kondisi fisik, emosional serta perilaku adalah manifestasi adanya kecemasan terhadap masa pensiun yang akan dihadapi. Tindakan yang dilakukan untuk mengurangi kecemasan yang timbul akibat masa pensiun yaitu dengan penyesuaian diri. Kondisi yang dirasakan responden memicu adanya reaksi tindakan untuk mencapai kesiapan dalam menghadapi masa pensiun. Kondisi yang tampak pada masa pra pensiun dapat dihadapi dengan melakukan serangkaian tindakan untuk mencapai penyesuaian diri.

Dalam penelitian ini, tindakan yang dilakukan individu untuk melakukan penyesuaian diri terbagi menjadi tindakan yang berorientasi kepada diri individu dan tindakan yang berorientasi pada orang lain. Tindakan yang dilakukan sesuai dengan gambaran perilaku yang tampak pada menjelang masa pensiun. Seperti yang dikemukakan oleh Erikson (dalam Feist \& Feist, 2010) memasuki masa pensiun manusia dewasa mengembangkan kualitas generativitas yang didefinisikan dengan menetapkan dan membimbing generasi selanjutnya. Pada fase ini, manusia memiliki kebutuhan untuk memberikan petunjuk tidak hanya berfokus pada diri sendiri namun meluas menjadi kepedulian terhadap orang lain.

Tindakan yang berorientasi pada diri individu ditunjukkan melalui mempersiapkaan rencana menjelang masa pensiun, menerapkan pola hidup sederhana, menciptakan rasa nyaman, serta selalu bersyukur. Mempersiapkan rencana merupakan bagian dari upaya individu untuk mencapai penyesuaian diri. Salah satu rencana responden ketika memasuki masa pensiun adalah melakukan hobi untuk mengisi waktu luang. Hobi yang dilakukan merupakan cara responden untuk mengatasi rasa lelah dengan melakukan kegiatan yang digemari. Sejalan dengan pernyataan Suardiman (2011) bahwa perencanaan pensiun akan membantu seseorang untuk mengevaluasi berbagai pilihan, belajar tentang ketersediaan sumber, dan menyiapkan secara emosional jika terjadi perubahan. Rencana yang dipersiapkan individu dalam penelitian ini antara lain keinginan membuka usaha agar menghasilkan uang, melakukan hobi untuk mengisi waktu luang, mengikuti kegiatan organisasi serta berpartisipasi aktif dalam kegiatan keagamaan.

Menerapkan pola hidup sederhana merupakan cara individu untuk mengatasi perubahan ekonomi yang terjadi ketika masa pensiun. Mulai menerapkan pola hidup sederhana telah dilakukan responden menjelang masa pensiun untuk membiasakan diri apabila perubahan ekonomi mulai terjadi. Sejalan dengan pernyataan Paidi (2013) bahwa upaya untuk melakukan penghematan pada masa pensiun, salah satunya dengan cara menerapkan gaya hidup sederhana.

Menciptakan rasa nyaman merupakan salah satu tindakan individu untuk mencapai kesiapan dalam menghadapi masa pensiun. Tindakan ini diwujudkan dengan cara menghindari 
konflik serta mengurangi tekanan sehingga individu mampu menciptakan kenyamanan pada masa pensiun. Sejalan dengan penelitian yang dilakukan oleh Sekarsari dan Susilawati (2015) individu yang akan memasuki masa pensiun mulai menerima dan membutuhkan dukungan dari lingkungan baik dari keluarga, rekan kerja maupun instansi untuk membantu menjalani masa pensiun yang baik dan terhindar dari konflik agar individu dapat mencapai kenyamanan dalam masa pensiun.

Tindakan lainnya yang dilakukan individu untuk mencapai kesiapan menjelang masa pensiun adalah selalu bersyukur. Selalu bersyukur diwujudkan individu dalam segala pencapaian yang telah diperoleh. Sejalan dengan pernyataan Suardiman (2011) bahwa dengan banyak bersyukur atas nikmat dan karunia yang diberikan merupakan manifestasi pengakuan terhadap kekuasaan Tuhan Yang Maha Esa. Kehidupan usia lanjut telah sampai pada tahapan kesadaran berserah diri kepada Tuhan Yang Maha Esa, keikhlasan untuk berserah diri membahwa seseorang kepada ketenangan dan tidak putus asa ketika mengalami masa-masa sulit.

Tindakan yang berorientasi pada orang lain ditunjukkan individu dengan cara berpartisipasi dalam kegiatan yang dilakukan di masyarakat serta berusaha berbuat baik. Berpartisipasi dalam kegiatan di masyarakat dilakukan individu sebagai bentuk pergantian karena sebelumnya individu kurang aktif dalam terjun ke masyarakat akibat kewajibannya di kantor. Melalui berpartisipasi dengan masyarakat, individu memupuk perbuatan baik yang memberikan rasa kenyaman dan ketenteraman ketika individu kembali ke masyarakat setelah memasuki masa pensiun.

\section{Faktor-faktor yang memengaruhi tindakan kesiapan menghadapi masa pensiun}

Peneliti menemukan beberapa faktor yang memengaruhi kesiapan responden dalam menghadapi masa pensiun. Faktorfaktor tersebut dibagi menjadi faktor pendukung dan faktor penghambat. Faktor pendukung kesiapan menghadapi pensiun adalah adanya persepsi positif yang terdiri dari persepsi positif terhadap tersedianya waktu luang serta tidak perlu khawatir karena selalu ada dukungan keluarga. Faktor pendukung lainnya berupa mencari dan memperoleh informasi positif mengenai masa pensiun di lingkungan kerja dan adanya dukungan dari keluarga.

Selain adanya persepsi positif mengenai penambahan waktu luang, persepsi mengenai selalu tersedianya dukungan dari keluarga menyebabkan responden merasa siap untuk menghadapi masa pensiun. Sejalan dengan penelitian yang dilakukan Fardila, Rahmi dan Putra (2014) bahwa terdapat hubungan yang signifikan antara dukungan sosial keluarga dengan kesiapan menghadapi pensiun pada Pegawai Negeri Sipil (PNS). Dukungan sosial dari keluarga dan teman terdekat dapat membantu individu untuk tetap semangat dan percaya diri dalam menghadapi realitas kehidupan yang sedang dihadapi.

Faktor pendukung lainnya yang memengaruhi kesiapan individu dalam menghadapi masa pensiun yaitu adanya informasi positif yang diberikan lingkungan kerja terhadap individu. Informasi yang diberikan oleh lingkungan kerja menambah pengetahuan individu mengenai masa pensiun. Selain memperoleh informasi dari lingkungan kerja, individu juga aktif untuk mencari informasi kepada rekan kerja yang masih aktif maupun telah memasuki masa pensiun terlebih dahulu. Ketersediaan informasi yang diberikan oleh lingkungan kerja menyebabkan individu merasa mampu melewati masa pensiun dengan baik. Sejalan dengan hasil penelitian yang dilakukan Setiyorini (2014) bahwa menjelang masa pensiun, pegawai perlu mendapatkan informasi yang cukup tentang pensiun untuk menambah kesiapan dan mengurangi kekhawatiran tentang pensiun.

Faktor penghambat individu dalam mencapai kesiapan pada masa pensiun yaitu konflik dengan anggota keluarga. Konflik dengan anggota keluarga seperti suami dan menantu menyebabkan individu gelisah serta tidak nyaman dalam melakukan persiapan menjelang masa pensiun. Fokus responden menjadi terbagi antara mempersiapkan masa pensiun atau penyelesaian konflik yang dialami. Diketahui bahwa keluarga merupakan kelompok sosial yang memiliki ikatan emosi terdekat dengan individu. Keluarga sebagai kelompok sosial yang memahami individu menunjukkan upaya-upaya yang dapat membantu individu dalam mengatasi perubahan menjelang masa pensiun. Sejalan dengan penelitian yang dilakukan Sekarsari dan Susilawati (2015) bahwa dukungan yang berasal dari keluarga merupakan dukungan paling utama yang dibutuhkan individu menjelang masa pensiun yaitu dalam bentuk dukungan emosional dan dukungan informasi. Selain itu, persiapan-persiapan membutuhkan dukungan sosial pada menjelang masa pensiun meliputi persiapan keuangan, kesehatan atau kebugaran, penyesuaian peran, kegiatan waktu luang, serta asuransi kesehatan.

\section{Dukungan Keluarga menjelang masa pensiun}

Pada penelitian ini, ditemukan bahwa keluarga memiliki peran penting bagi individu menjelang masa pensiun. Keluarga menjadi kelompok sosial yang dapat membantu individu dalam mencapai kesiapan menghadapi masa pensiun. Dukungan dari keluarga memberikan kenyamanan pada individu untuk mampu mempersiapkan masa pensiun dengan sebaik-baiknya. Bentuk dukungan keluarga dalam penelitian terdiri dari enam kategori yaitu:

\section{Place to share and discuss}

Place to share and discuss merupakan bentuk dukungan dari keluarga yang bersedia menjadi sumber berbagi dan berdiskusi dari individu menjelang masa pensiun. Bentuk dukungan ini memungkinkan individu untuk mengembangkan serta mencari informasi mengenai masa pensiun. Sejalan dengan pernyataan Azizah (2011) mengenai dukungan informasi serta dukungan emosional yang menyatakan bahwa dukungan informasi melibatkan pemberian informasi, saran serta umpan balik tentang situsasi dan kondisi individu sedangkan dukungan emosional membuat individu merasa nyaman, yakin, diperdulikan dan dicintai oleh sumber dukungan sosial. Bentuk dukungan place to share and discuuss mencakup pada individu dapat melakukan diskusi dengan keluarga bahkan sekaligus keluarga memberikan perhatian kepada individu 
mengenai masa pensiun.

\section{Energizer}

Energizer merupakan bentuk dukungan keluarga yang memberikan pengaruh positif pada penerima dukungan. Pengaruh positif yang diberikan oleh keluarga menjadikan individu merasa mampu untuk melawan kondisi-kondisi yang sulit terkait masa pensiun. Bentuk dukungan ini diwujudkan dengan memberikan semangat, mendukung persiapan, perasaan senang keluarga karena dapat menghabiskan banyak waktu dengan individu sehingga meningkatkan rasa percaya diri yang dirasakan individu penerima dukungan dalam menghadapi masa pensiun.

Sejalan dengan pernyataan mengenai dukungan emosional oleh Friedman (1998) bahwa dukungan emosional diterima oleh individu yang menghadapi pensiun dapat membantunya menumbuhkan atau meningkatkan rasa percaya diri dan harga diri sehingga mampu membantu seseorang untuk menghasilkan pemikiran strategis yang bisa meninjau dan menilai hal-hal positif yang saat ini dimilikinya. Azizah (2011) menyatakan mengenai dukungan harga diri yaitu bentuk dukungan berupa penghargaan positif pada individu, pemberian semangat, serta perbandingan yang positif dengan orang lain. Dukungan ini membantu individu dalam membangun harga diri serta kompetensi sehingga dapat menghadapi masa pensiun dengan lebih positif.

$\underline{\text { Be reminder }}$

Be reminder merupakan bentuk dukungan keluarga yang ditandai dengan peringatan yang diberikan oleh keluarga kepada individu apabila individu melakukan tindakan yang cenderung memberikan dampak negatif terhadap individu dan lingkungan sekitarnya..

Sejalan dengan pernyataan Setyaningsih dan Mu'in (2013) mengenai dukungan sosial bahwa dukungan sosial merupakan suatu bentuk hubungan interpersonal yang memberikan bantuan kepada individu berupa perhatian, emosi, bantuan instrumental, pemberian informasi, dan penilaian kepada individu oleh lingkungan sosialnya sehingga individu dapat bertindak sesuai dengan norma- norma yang berlaku di masyarakat.

\section{Financial Source}

Financial Source merupakan salah satu bentuk pemberian bantuan financial kepada individu untuk meringankan beban individu ketika menghadapi masa pensiun. Bentuk dukungan ini diwujudkan dengan membantu dalam menanggung pengeluaran keluarga. Dukungan berupa bantuan financial sejalan dengan pernyataan mengenai dukungan instrumental oleh Sarafino dan Smith (2012) yaitu dukungan instrumental melibatkan bantuan langsung, seperti ketika seseorang memberikan atau meminjamkan uang atau membantu dalam pekerjaan dan kondisi yang dihadapi individu yang menerima bantuan.

\section{Fasilitator}

Fasilitator merupakan bentuk dukungan keluarga terhadap individu dengan cara meringankan beban individu dalam penyediaan fasilitas yang mendukung kegiatan individu ketika masa pensiun. Dukungan ini diwujudkan dengan membantu memperbaiki peralatan yang digunakan untuk menjalankan hobi pada masa pensiun. Dukungan sebagai fasilitator dalam penyediaan peralatan untuk mejalankan hobi sejalan dengan pernyataan Johnson dan Johnson (dalam Ermayanti \& Abdullah, 2007) mengenai dukungan instrumental bahwa dukungan ini merupakan dukungan nyata berupa bantuan yang bersifat langsung seperti pemberian uang, peralatan, serta pekerjaan yang dibutuhkan. Haber (2010) juga menyatakan mengenai dukungan instrumental bahwa penyediaan barang atau jasa dan secara langsung dapat membantu individu yang membutuhkan. Dukungan ini dapat menurunkan tekanan emosi serta meningkatkan kepuasan hidup individu.

Taking over the job

Taking over the job merupakan bantuan keluarga untuk mengambil alih pekerjaan yang menjadi tanggung jawab individu namun tidak dapat terselesaikan oleh individu. Dukungan ini diwujudkan melalui membantu responden melakukan ayah-ayahan di banjar. Selama aktif dalam menjalani pekerjaan sebagai Pegawai Negeri Sipil (PNS), responden harus disiplin dalam membagi waktu antara urusan pribadi dan urusan kantor. Tidak jarang responden mengorbankan urusan pribadi yang menjadi tanggung jawab responden demi kewajiban responden di kantor. Responden diharuskan untuk memilih prioritas utama namun tetap menjalankan kewajiban lainnya.

Dalam penelitian ini, bentuk dukungan yang diberikan oleh keluarga untuk meringankan beban kewajiban responden adalah dengan mengambil alih pekerjaan responden. Responden merasa terbantu dengan adanya dukungan yang diberikan oleh keluarga kepada responden. Sejalan dengan pernyataan Azizah (2011) bahwa salah satu manfaat dari dukungan keluarga adalah meringankan beban bagi seseorang yang sedang mengalami masalah atau persoalan.

\section{Kesimpulan dan Saran}

\section{Kesimpulan}

Berdasarkan hasil dan pembahasan yang telah dijelaskan pada bab Bab IV penelitian ini, maka dapat disimpulkan beberapa hal sebagai berikut: (1) Gambaran masa pra pensiun yang dihadapi Pegawai Negeri Sipil perempuan meliputi, kondisi fisik, kondisi emosional, serta perilaku. (2) Tindakan yang dilakukan untuk mencapai kesiapan dalam menghadapi masa pensiun dikategorikan sebagai tindakan yang berorientasi pada diri sendiri atau self dan tindakan yang berorientasi terhadap orang lain atau others. Tindakan-tindakan tersebut meliputi mempersiapkan rencana terkait masa pensiun, mulai menerapkan pola hidup sederhana, menciptakan rasa nyaman, selalu bersyukur, berpartisipasi dalam kegiatan di masyarakat serta selalu berusaha berbuat baik. (3) Faktor yang memengaruhi tindakan untuk mencapai masa pensiun terdiri dari faktor pendukung serta faktor penghambat, faktor pendukung untuk mencapai kesiapan masa pensiun antara lain adanya persepsi positif, menerima informasi positif mengenai masa pensiun dari lingkungan kerja serta tersedianya dukungan dari keluarga. Faktor penghambat dalam mencapai kesiapan masa pensiun yakni adanya konflik dengan anggota keluarga. (4) Penelitian ini menemukan, bentuk dukungan keluarga pada perempuan pra pensiun terdiri dari place to share and discuss, energizer, be reminder, financial source, fasilitator, serta taking over the job. 


\section{$\underline{\text { Saran }}$}

Berdasarkan hasil penelitian dan pembahasan, hal-hal yang dapat direkomendasikan oleh peneliti antara lain sebagai berikut :

Saran kepada perempuan pra pensiun Pegawai Negeri Sipil

Diharapkan kepada perempuan pada masa pra pensiun untuk bersikap terbuka terhadap hubungan sosial di lingkungan sekitar. Tetap menjaga hubungan baik dengan lingkungan sekitar dapat berpengaruh terhadap kesiapan individu dalam menghadapi masa pensiun. Selain menjaga hubungan baik dengan lingkungan sekitar, disarankan pula beberapa tindakan yang dapat dilakukan perempuan pra untuk mencapai kesiapan memasuki masa pensiun antara lain mulai mempersiapkan rencana terkait masa pensiun, mulai menerapkan pola hidup sederhana, menciptakan rasa nyaman, selalu bersyukur, tetap melakukan aktivitas dengan cara berpartisipasi dalam kegiatan di masyarakat serta selalu berusaha berbuat baik.

\section{$\underline{\text { Saran kepada pihak keluarga }}$}

Diharapkan keluarga tetap memberikan informasi terkait masa pensiun sehingga individu memperoleh referensi dalam menemukan kegiatan yang tepat serta pengambilan keputusan dalam menentukan rencana individu setelah memasuki masa pensiun. Keluarga disarankan untuk selalu menjadi sumber dukungan bagi perempuan pra pensiun agar mampu mempersiapkan masa pensiun dengan sebaik-baiknya.

Saran kepada rekan kerja

Saran yang dapat diberikan oleh peneliti kepada rekan kerja yaitu diharapkan rekan kerja untuk memberikan dukungan terhadap individu di sekitar lingkungan kerja yang akan memasuki masa pensiun. Dukungan yang dapat diberikan berupa sharing dan berdiskusi serta mendengar keluh kesah individu mengenai masa pensiun. Hal tersebut dapat memberikan informasi yang berguna bagi individu dalam menghadapi masa pensiun. Adanya dukungan yang diberikan oleh rekan kerja dapat membantu individu mencapai kesiapan untuk menghadapi masa pensiun.

Saran kepada pemerintah

Saran yang dapat diberikan kepada pemerintah apabila pemerintah berencana untuk merancang suatu program intervensi kepada perempuan yang akan memasuki masa pensiun maka sebaiknya program intervensi tersebut dapat disesuaikan dengan gambaran masa pra pensiun yang dihadapi oleh perempuan yang akan memasuki masa pensiun yaitu meliputi aspek fisik, emosional serta perilaku. Diharapkan pemerintah dapat memberikan program pelatihan kepada pegawai yang akan memasuki masa pensiun. Pelatihan tersebut dapat berupa pelatihan bagaimana merencanakan masa pensiun, pelatihan wirausaha untuk melakukan kegiatan usaha setelah memasuki masa pensiun, pelatihan cara hidup hemat melalui financial planning, pelatihan dalam mengembangkan fikiran positif, relaksasi, serta meditasi yang dapat menciptakan kenyamanan dalam menjalankan masa pensiun.

\section{DAFTAR PUSTAKA}

Adityawira, I. K. Y, \& Supriyadi. (2017). Hubungan konflik kerja keluarga terhadap motivasi kerja dengan dukungan sosial sebagai variabel pemoderasi pada perawat wanita di Rumah Sakit di Bali. Jurnal Psikologi Udayana, 4 (1). 183-197.
Azizah, L.M. (2011). Keperawatan lanjut usia. Yogyakarta: Graha Ilmu.

Badan Pusat Statistik Provinsi Bali . (2016). Jumlah penduduk Provinsi Bali yang bekerja menurut jenis pekerjaan/ jabatan dalam pekerjaan utama tahun 2006-2016. Diunduh dari https://bali.bps.go.id/dynamictable/2018/02/28/260/pendud uk-usia- 15-tahun-ke-atas-yang-bekerja-menurut-jenispekerjaan-jabatan-dalam-pekerjaan- utama-2006-2016.html

Badan Pusat Statistik. (2016). Jumlah Pegawai Negeri Sipil Menurut Provinsi dan Jenis Kelamin tahun 2007-2016. Diunduh dari https://www.bps.go.id/statictable/2013/12/31/1163/jumlahpegawai-negeri-sipil- menurut-provinsi-dan-jenis-kelamin2007-2016.html

Basuki, W. (2015). Faktor-faktor penyebab kesepian terhadap tingkat depresi pada lansia penghuni panti sosial tresna werdha nirwana puri Kota Samarinda, 4 (1), 713-750.

Biya, C.I.M.J, \& Suarya, L.M.K.S. (2016). Hubungan dukungan sosial dan penyesuaian diri pada masa pensiun pejabat struktural di pemerintahan provinsi bali. Jurnal Psikologi Udayana, 3 (2), 354-362.

Creswell, J.W. (2015). Penelitian kualitatif \& desain riset. (Alih Bahasa: Lazuardi, A.L).

Yogyakarta: Pustaka Belajar.

Dinsi, V., Setiati, E. , \& Yuliasari, E. (2006). Ketika pensiun tiba. Jakarta : Wijayata Media Utama.

Ermayanti, S., \& Abdullah, S. M. (2007). Hubungan antara persepsi terhadap dukungan sosial dengan penyesuaian diri pada masa pensiun. Jurnal Insight, 5 (1), 148-170.

Fardila, N., Rahmi, T., \& Putra, Y.Y. (2014). Hubungan dukungan sosial keluarga dengan kesiapan menghadapi pensiun pada pegawai negeri sipil. Jurnal RAP UNP, 5 (2), 157-168.

Feist, J. \& Feist, G.J. (2010). Teori Kepribadian. Jakarta: Salemba Humanika. Friedman, M. M. (1998). Keperawatan Keluarga: Teori dan Praktik. Jakarta: EGC.

Greenberg, J. S. (2004). Comprehensive stress management (7th ed.). New York: The McGraw-Hill Companies.

Haber, D. (2010). Health Promotion and Aging: Practical Applications for Health Professionals, Fifth Edition. New York: Springer Publishing Company.

Hasanah, H. (2016). Teknik-teknik observasi (sebuah alternatif metode pengumpulan data kualitatif ilmu-ilmu sosial). Jurnal at-Taqaddum, 8 (1), 21-46.

Herani, U. \& Indriana, Y. (2015). Hubungan antara regulasi diri dengan kecenderungan post power syndrome pada pensiunan pegawai negeri sipil anggota paguyuban pensiunan pendidikan Kabupaten Tegal. Jurnal Empati. 4 (2), 139-145.

Hermaningtyas, D.P., Mardijana, A., \& Dewi, R. (2015). Hubungan antara masa persiapan pensiun dan kecenderungan depresi pada pegawai negeri sipil (PNS) di Universitas Jember. Artikel Ilmiah Hasil Penelitian Mahasiswa 2015, 1-4.

Holmes, T. H., \& Rahe, R. H. (1967). The social readjustment rating scale. Journal of Psychosomatic Research, 11, 213-288.

Isnawati, D., \& Suhariadi, H.F. (2013). Hubungan dukungan sosial dengan penyesuaian diri masa persiapan pensiun pada karyawan PT. Pupuk Kaltim. Jurnal Psikologi Industri dan Organisasi, 02 (1), 1-6.

Kumalasari, F. (2012). Hubungan antara dukungan sosial dengan penyesuaian diri remaja di panti asuhan. Jurnal Psikologi Pitutur, 1 (1), 21-31.

Matlin, M. W. (2008). The psychology of women, 6th ed. USA: Thomson Wadsworth. Moleong, L. J. (2015). Metode Rosdakarya penelitian kualitatif (edisi revisi). Bandung: PT. Remaja

Nilakusumawati, D. P., \& Susilawati, M. (2012). Studi faktor-faktor yang mempengaruhi wanita bekerja di kota denpasar. Jurnal 
Kependudukan dan Pengembangan Sumber Daya Manusia, 8 (1), 26-31

Paidi (2013). Strategi persiapan masa pensiun bagi para karyawan. EJournal Widya Ekonomika, 1 (1), 12-17.

Pratiwi, D. A. D. P. (2017). Dukungan sosial dan penyesuaian diri pada perempuan pra pensiun Pegawai Negeri Sipil di Provinsi Bali. (artikel tidak dipublikasikan). Program Studi Psikologi, Fakultas Kedokteran, Universitas Udayana, Bali.

Rachmaputri, R., \& Haryanti, K. (2015). Hubungan dukungan sosial keluarga dan kepuasan kerja dengan work-family conflict pada anggota ikatan wanita pengusaha Indonesia (IWAPI) Jawa Tengah. Psikodimensia, 14 (2), 55-73.

Safitri, B., R. (2013). Kesiapan menghadapi masa pensiun ditinjau dari peran gender karyawan. Jurnal Ilmiah Psikologi Terapan, 1 (2), 191-204.

Sarafino, E.P. \& Smith, T.W. (2012). Health psychology: biopsychosocial interactions (7th ed.). Canada: John Milley and Sons Inc.

Sekarsari, N.K.W.D., \& Susilawati, L.K.P.A. (2015). Bentuk-bentuk dukungan sosial pada pegawai negeri sipil menjelang masa pensiun. Jurnal Psikologi Udayana, 2(2), 172-184.

Setyaningsih, S. \& Mu'in, M. (2013). Dukungan sosial dan tingkat kecemasan pada kelompok pekerja pns yang menghadapi masa pensiun. Jurnal Keperawatan Komunitas , 01, 116121.

Setiyorini, M. (2014). Pengaruh identitas sosial sebagai pegawai senior, karakteristik pekerjaan, dukungan sosial dan kejenuhan pada sikap pegawai tentang pekerjaan dan pensiun. Jurnal Bisnis dan Manajemen, 14 (1), 47-62.

Strauss, A. \& Corbin, J. (1990). Basic of qualitative reaserch. California: Sage. Suardiman, S. (2011). Psikologi Usia Lanjut. Yogyakarta: Gadjah Mada University Press. 


\section{LAMPIRAN}

Gambar 1

Gambaran Penyesuaian Diri Perempuan Pra Pensiun

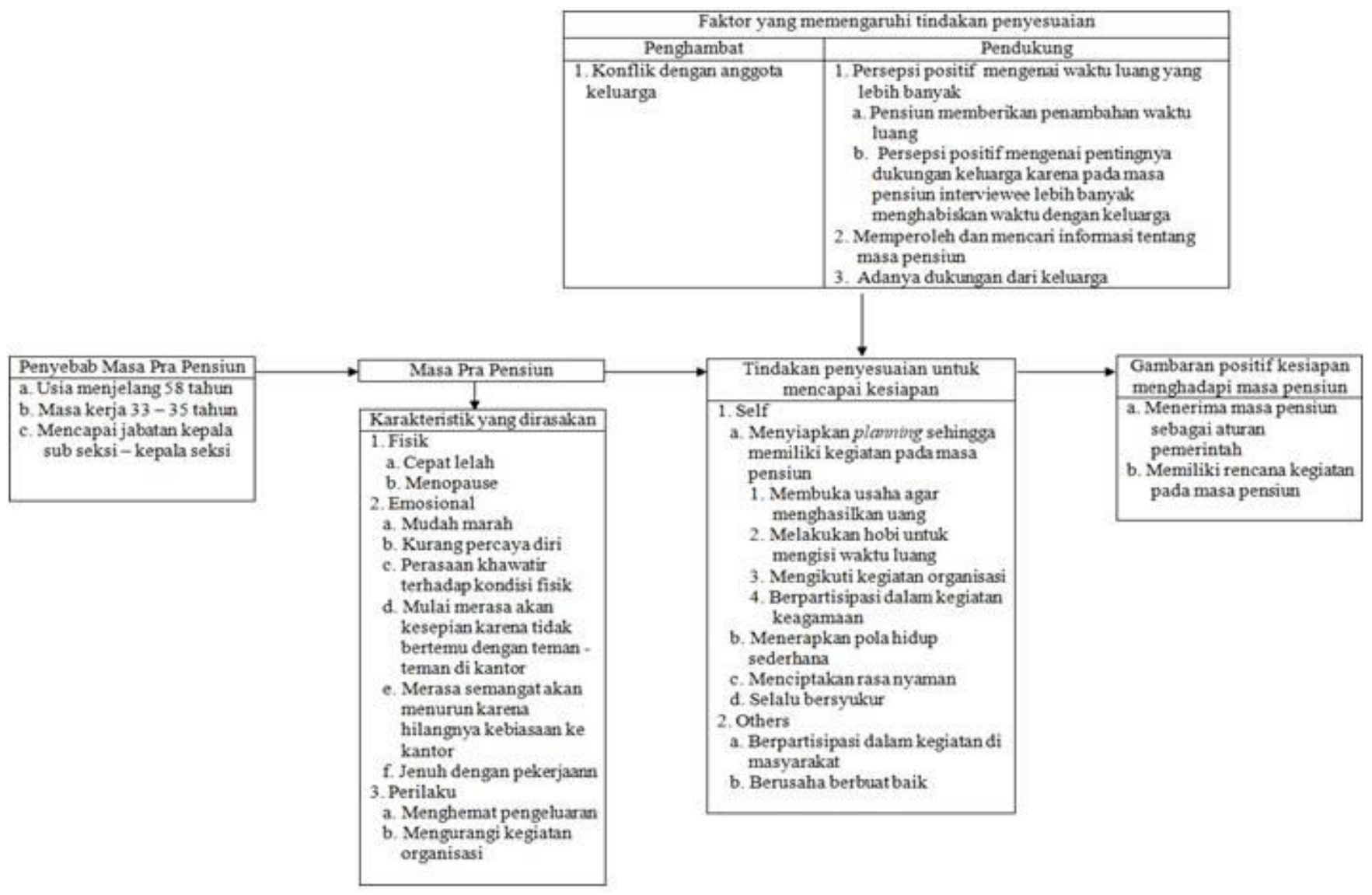


Gambar 2

Dukungan Keluarga

\begin{tabular}{|c|c|}
\hline Bentuk dukungan & Perilaku \\
\hline \multirow[t]{6}{*}{ 1. Place to share and discuss } & a. Berdiskusi terkait kegiatan yang dilakukan pada masa pensiun \\
\hline & $\begin{array}{l}\text { b.Mengkomunikasikan kepada anak perempuan terkait masa pensiun yang } \\
\text { akan dihadapi }\end{array}$ \\
\hline & $\begin{array}{l}\text { c.Menceritakan kepada keluarga bahwa kapan interverview memasuki } \\
\text { masa pensiun }\end{array}$ \\
\hline & $\begin{array}{l}\text { d.Keluarga memberikan pertimbangan terkait kegiatan yang dapat } \\
\text { dilakukan pada masa pensiun }\end{array}$ \\
\hline & e.Mendengarkan keluh kesah interviewee \\
\hline & $\begin{array}{l}\text { f.Memberikan informasi terkait kegiatan yang dapat interviewee lakukan } \\
\text { padapensiun }\end{array}$ \\
\hline
\end{tabular}

g.Memberikan argument jika dimintai pendapat oleh interviewee

2.Energizer h.Membenkan semangat kepada interviewee

i.Mendukung persiapan pensiun interviewee

j.Keluarga senang karena interviewee dapat menghabiskan banyak waktu dengan keluarza

3.Be reminder $\quad$ k.Mengingatkan apabila interviewee keliru

\begin{tabular}{ll}
\hline 4.Financial Source & L.Membantu dalam menanggung pengeluaran keluarga \\
\hline 5.Fasilitator & $\begin{array}{l}\text { m.Membantu memperbaiki peralatan yang digunakan untuk menjalankan } \\
\text { hobi pada masa pensiun }\end{array}$ \\
\hline 6.Taking over the job & $\begin{array}{l}\text { n.Membantu interviewee melakukan ayah - ayahan di } \\
\text { banjar }\end{array}$ \\
\hline
\end{tabular}

